\title{
Discovery of Walnut Twig Beetle, Pityophthorus juglandis, Associated with Forested Black Walnut, Juglans nigra, in the Eastern U.S.
}

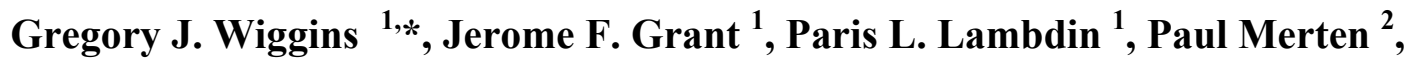 \\ Katheryne A. Nix ${ }^{1}$, Denita Hadziabdic ${ }^{1}$ and Mark T. Windham ${ }^{1}$
}

1 Department of Entomology and Plant Pathology, 2505 E.J. Chapman Drive, 370 Plant Biotechnology Building, The University of Tennessee, Knoxville, TN 37996-4560, USA; E-Mails: jgrant@utk.edu (J.F.G.); plambdin@utk.edu (P.L.L.); kavery3@utk.edu (K.A.N.); dhadziab@utk.edu (D.H.); mwindham@utk.edu (M.T.W.)

2 USDA Forest Service Forest Health Protection, 200 W.T. Weaver Boulevard, Asheville, NC 28806, USA; E-Mail: pmerten@fs.fed.us

* Author to whom correspondence should be addressed; E-Mail: wiggybug@utk.edu; Tel.: +1-865-974-6405; Fax: +1-865-974-4744.

Received: 18 March 2014; in revised form: 9 May 2014 / Accepted: 21 May 2014 /

Published: 28 May 2014

\begin{abstract}
Thousand cankers disease (TCD) is an insect-mediated disease of walnut trees (Juglans spp.) involving walnut twig beetle (Pityophthorus juglandis) and a fungal pathogen (Geosmithia morbida). Although first documented on walnut species in the western U.S., TCD is now found on black walnut (J. nigra) in five states in the eastern U.S. Most collections of $P$. juglandis or G. morbida are from trees in agriculturally- or residentially-developed landscapes. In 2013, 16 pheromone-baited funnel traps were deployed in or near black walnuts in forested conditions to assess the risk of infestation of forested trees by $P$. juglandis. Four of the 16 funnel traps collected adult $P$. juglandis from three forested areas (one in North Carolina and two in Tennessee). These collections, while in forested settings, may still be strongly influenced by human activities. The greatest number of $P$. juglandis $(n=338)$ was collected from a forested location in an urbanized area near a known TCD-positive tree. The other two forested locations where $P$. juglandis $(n=3)$ was collected were in areas where camping is common, and infested firewood may have introduced $P$. juglandis unintentionally into the area. Future studies to assess $P$. juglandis on more isolated forested walnuts are planned.
\end{abstract}


Keywords: walnut twig beetle; Pityophthorus juglandis; Geosmithia morbida; thousand cankers disease; black walnut; Juglans nigra

\section{Introduction}

Black walnut, Juglans nigra, is native to the eastern and midwestern U.S., where it is widely distributed across a variety of sites from open fields to forests [1]. Black walnut is highly valued for its wood and nut production, and the value of existing trees in its native range is estimated at over $\$ 539$ billion [2]. Beginning in 2001, widespread mortality of black walnut was documented in Colorado and other states in the western U.S. where it had been transplanted and naturalized in many areas [2,3]. Researchers concluded that this mortality was caused by a newly-documented disease known as thousand cankers disease (TCD) [3]. This disease complex involves the fungus Geosmithia morbida (Ascomycota: Hypocreales: Bionectriaceae) vectored by the walnut twig beetle, Pityophthorus juglandis (Coleoptera: Curculionidae), which is native to the western U.S. [2,4]. This disease is known to affect all Juglans species [5], with the highest susceptibility observed in black walnut [3]. Although infected walnut trees in the western U.S. typically die two to three years following manifestation of disease symptoms [3], P. juglandis and G. morbida may be present in the tree for five to ten years before trees appear symptomatic [6].

Prior to 2010, this disease was believed to be restricted to the western U.S., where it was originally discovered and described. In July 2010, TCD was documented for the first time in the native range of black walnut in the eastern U.S. in Tennessee. Both P. juglandis and G. morbida were confirmed from black walnut trees in Knoxville, Knox County, Tennessee [7,8] (Figure 1). Since this initial find in the eastern U.S., TCD has been found in eight other Tennessee counties, as well as in Pennsylvania [9] and Virginia [10] in 2011, North Carolina [11] in 2012, and Ohio [12] in 2013. This disease is now of international concern, as TCD was found in J. nigra in Italy in 2013 [13]. Scientists and regulatory agencies have investigated the extent of TCD in the U.S. using both branch sampling of symptomatic trees [8] and deployment of pheromone-baited traps [14]. In the eastern U.S. black walnut is most often associated with open and/or marginal habitats, and much of the efforts to sample infested/infected trees and trap for $P$. juglandis have been conducted in agricultural or urban/residential settings. However, more than 306 million black walnuts are estimated to grow in forested conditions throughout its native range [15]. In counties in the eastern U.S. known to have $P$. juglandis, walnuts in forests can reach densities as high as 26.5 trees/ha [15]. Additionally, in some areas where TCD is not currently documented, forested black walnut densities can exceed 170 trees/ha [15]. Because $P$. juglandis is believed to be the main means of dispersal of G. morbida, a need exists to determine if forested trees are susceptible to infestation by $P$. juglandis.

To investigate the occurrence and distribution of $P$. juglandis on black walnut in forests, a multi-year project was initiated in 2012. During 2012, branch sampling was conducted in 20 locations throughout eastern Tennessee. While G. morbida-infected trees were documented on the forest edges at two locations in the Great Smoky Mountains National Park (GRSM) (Big Creek and Cataloochee Cove; Figure 1) [11], no P. juglandis was confirmed from black walnut at any sampled location. In 2013, this project was expanded to include pheromone-baited trapping [14], and the information presented here is 
associated with trapping conducted on forested black walnuts in eastern Tennessee and western North Carolina during 2013.

Figure 1. Location of initial documentation of thousand cankers disease in the eastern U.S. in Knox County, Tennessee, in 2010 (stars), and locations where forested walnuts were sampled for Pityophthorus juglandis: Big Creek (A), Cades Cove (B), Cataloochee Cove (C), Loyston Point (D), Maryville College (E), and Sugarlands Trail (F).

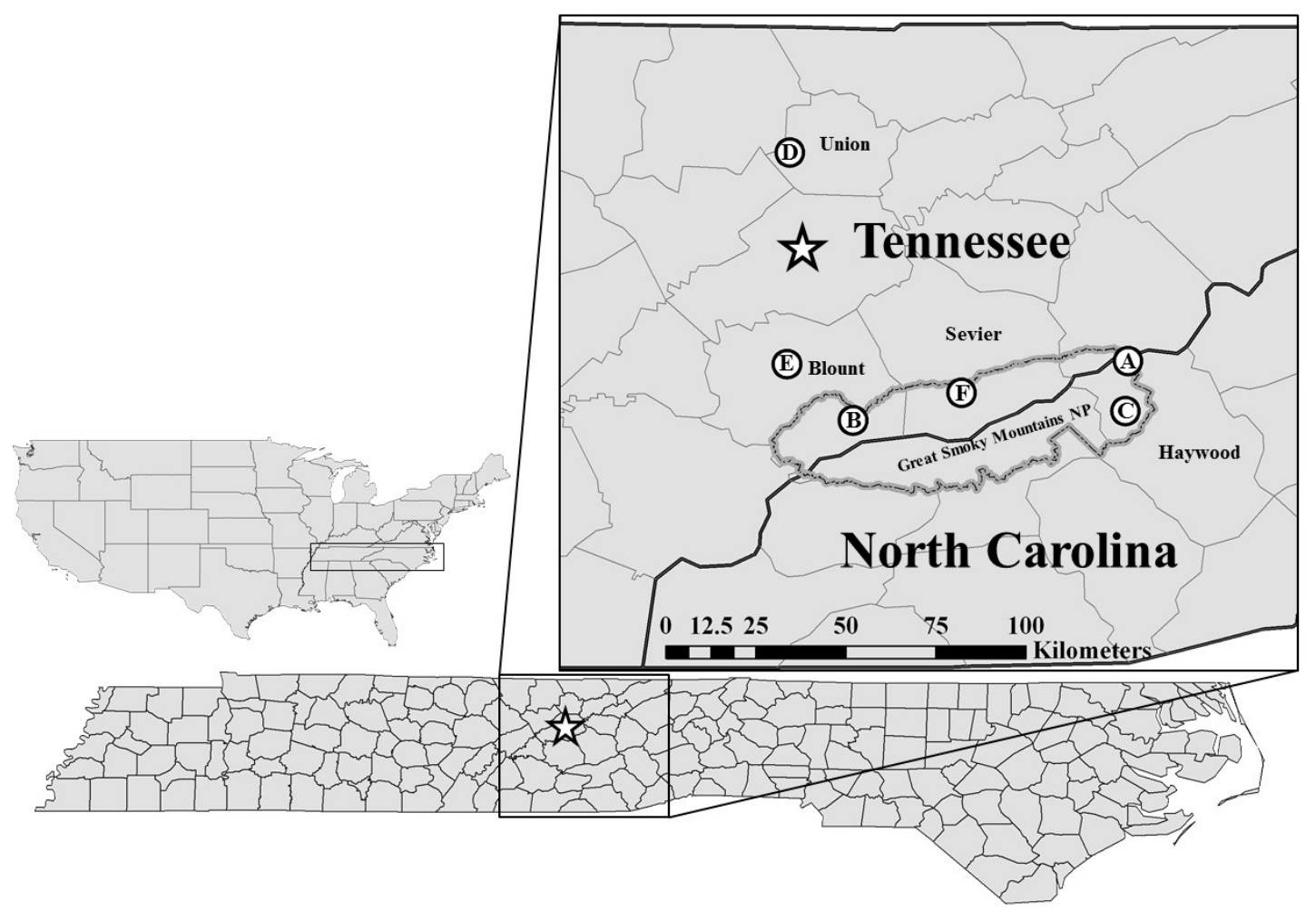

\section{Forested Black Walnut Assessment}

Trapping locations were determined upon consultation with land managers from GRSM (two locations in Haywood County, North Carolina (GRSM Big Creek and GRSM Cataloochee Cove) and one location each in Blount (GRSM Cades Cove) and Sevier Counties (GRSM Sugarlands Trail), Tennessee), Tennessee Valley Authority (TVA) (one location (TVA Loyston Point) Union County, Tennessee) and Maryville College (one location (Maryville College) Blount County, Tennessee) from May through July 2013 (Table 1). All trapping was conducted in counties known to have TCD [11,16]. Black walnuts at each location were in mixed hardwood forests of the yellow poplar-white oak-northern red oak forest cover type (Type 59) [1,17], and black walnut was a minor component at all locations. These locations were examined for TCD-symptomatic trees [8], and numbers of traps deployed at each location varied based on the number of symptomatic trees found. Trees were determined to be in forested conditions according to the U.S. Department of Agriculture Forest Service (USDA FS) definition of forested conditions as (1) at least 10\% stocked by forest-associated trees; (2) not developed for non-forest use; (3) at least 0.40 ha in size; and (4) at least $37.6 \mathrm{~m}$ wide [18]. Traps were placed between $30 \mathrm{~m}$ and $180 \mathrm{~m}$ from the forest edge (to reduce edge influences) in or near trees that appeared symptomatic and met the criteria for forested conditions (Table 1). The traps placed near 
symptomatic black walnut trees at the Maryville College site were within $200 \mathrm{~m}$ of one of the opengrown trees from which both P. juglandis and G. morbida were originally documented in 2010 . In addition to the traps in forested black walnut at the Big Creek and Cataloochee Cove sites, one trap was deployed in each of the two trees on the forest edge from which G. morbida was documented in North Carolina during 2012 [11] in an attempt to collect P. juglandis from these infected trees. Trap trees at the Cades Cove, Loyston Point, and Sugarlands Trail locations had no known TCD-infected trees within $5 \mathrm{~km}$.

Table 1. Locations and individual traps in forested conditions with reported number of Pityophthorus juglandis in North Carolina and Tennessee, 2013.

\begin{tabular}{|c|c|c|c|c|c|}
\hline Trap Name & State & County & Date Deployed & Distance $(m)^{3}$ & No. $P . j .{ }^{4}$ \\
\hline GRSM ${ }^{1}$ Big Creek 01 & $\mathrm{NC}$ & Haywood & 23 May & 110 & 0 \\
\hline GRSM Big Creek 02 & $\mathrm{NC}$ & Haywood & 29 May & 100 & 1 \\
\hline GRSM Big Creek 03 & $\mathrm{NC}$ & Haywood & 29 May & 100 & 0 \\
\hline GRSM Big Creek 04 & $\mathrm{NC}$ & Haywood & 29 May & 45 & 0 \\
\hline GRSM Big Creek 05 & $\mathrm{NC}$ & Haywood & 29 May & 65 & 0 \\
\hline GRSM Cades Cove 01 & $\mathrm{TN}$ & Blount & 11 July & 42 & 0 \\
\hline GRSM Cataloochee Cove 01 & $\mathrm{NC}$ & Haywood & 23 May & 35 & 0 \\
\hline GRSM Sugarlands Trail 01 & $\mathrm{TN}$ & Sevier & 26 June & 60 & 0 \\
\hline GRSM Sugarlands Trail 02 & $\mathrm{TN}$ & Sevier & 26 June & 135 & 0 \\
\hline GRSM Sugarlands Trail 03 & $\mathrm{TN}$ & Sevier & 26 June & 177 & 0 \\
\hline Maryville College 01 & $\mathrm{TN}$ & Blount & 12 July & 70 & 168 \\
\hline Maryville College 02 & $\mathrm{TN}$ & Blount & 12 July & 92 & 170 \\
\hline TVA $^{2}$ Loyston Point 01 & $\mathrm{TN}$ & Union & 15 May & 67 & 0 \\
\hline TVA Loyston Point 02 & $\mathrm{TN}$ & Union & 15 May & 53 & 2 \\
\hline TVA Loyston Point 03 & $\mathrm{TN}$ & Union & 15 May & 48 & 0 \\
\hline TVA Loyston Point 04 & $\mathrm{TN}$ & Union & 15 May & 33 & 0 \\
\hline
\end{tabular}

Notes: ${ }^{1}$ Traps located within the Great Smoky Mountains National Park; ${ }^{2}$ Traps located within Tennessee Valley Authority land holdings; ${ }^{3}$ Approximate distance in meters from the forest edge; ${ }^{4}$ Total number of $P$. juglandis collected from trap.

Sixteen traps were deployed in forests to trap for $P$. juglandis. The first traps were deployed at the Loyston Point location on 15 May 2013, and the last traps to be deployed were at the Maryville College location on 12 July (Table 1). Trapping was conducted by suspending a single four-unit black plastic Lindgren trap (Synergy Semiochemicals Corp., Burnaby, BC, Canada) baited with a $P$. juglandis-specific pheromone lure [19] from a branch ca. six to $12 \mathrm{~m}$ from ground level. Traps were either suspended in the canopy of a symptomatic black walnut or in a neighboring tree not more than $6 \mathrm{~m}$ from a symptomatic tree at each location. The collection cup $(500 \mathrm{~mL})$ of each trap contained ca. $125 \mathrm{~mL}$ of a preservative mixture of equal parts propylene glycol and water, and trap cups were changed bi-weekly (ca. 14-day interval) through October 2013. On each sampling date, the preservative mixture was transferred in the field from the collection cup to individually labeled 250-mL plastic bottles, taken to the laboratory, and examined for P. juglandis. Specimens from each suspected collection of $P$. juglandis were sent to Donald Bright and Whitney Cranshaw, Colorado State University, for confirmation of species identification. 


\section{Findings and Future Directions}

Adult P. juglandis were collected from four of 16 traps at two forested locations in Tennessee (Blount and Union Counties) and one forested location in North Carolina (Haywood County) (Tables 1 and 2). One $P$. juglandis was collected relatively early in the season on 31 May, and the remaining beetles were collected later in the season from 31 July to 22 October (Table 2). No P. juglandis were collected from either forest edge tree where G. morbida was found in North Carolina in 2012, but the collection of $P$. juglandis at Big Creek was from a trap ca. $100 \mathrm{~m}$ from the G. morbida-positive tree. No P. juglandis were collected from Cades Cove or Sugarlands Trail sites. The greatest number of beetles was collected from Maryville College $(n=338)$, and the number of $P$. juglandis in traps peaked on 14 August (Maryville College 02) and 9 October (Maryville College 01) (Table 2).

Table 2. Individual trap collections and collection dates of Pityophthorus juglandis from black walnuts in forested conditions, North Carolina and Tennessee, 2013.

\begin{tabular}{cccccc}
\hline Trap Name & State & County & Collection Date & Distance (m) & No. P.j. $^{\mathbf{4}}$ \\
\hline GRSM ${ }^{1}$ Big Creek 02 & NC & Haywood & 06 August & 100 & 1 \\
Maryville College 01 & TN & Blount & 31 July & 70 & 30 \\
Maryville College 01 & TN & Blount & 14 August & 70 & 25 \\
Maryville College 01 & TN & Blount & 28 August & 70 & 3 \\
Maryville College 01 & TN & Blount & 13 September & 70 & 1 \\
Maryville College 01 & TN & Blount & 26 September & 70 & 35 \\
Maryville College 01 & TN & Blount & 09 October & 70 & 58 \\
Maryville College 01 & TN & Blount & 22 October & 70 & 18 \\
Maryville College 02 & TN & Blount & 31 July & 92 & 15 \\
Maryville College 02 & TN & Blount & 14 August & 92 & 67 \\
Maryville College 02 & TN & Blount & 28 August & 92 & 15 \\
Maryville College 02 & TN & Blount & 13 September & 92 & 15 \\
Maryville College 02 & TN & Blount & 26 September & 92 & 15 \\
Maryville College 02 & TN & Blount & 09 October & 92 & 20 \\
Maryville College 02 & TN & Blount & 22 October & 92 & 21 \\
TVA ${ }^{2}$ Loyston Point 02 & TN & Union & 31 May & 53 & 1 \\
TVA Loyston Point 02 & TN & Union & 07 August & 53 & 1 \\
\hline
\end{tabular}

${ }^{1}$ Traps located within the Great Smoky Mountains National Park; ${ }^{2}$ Traps located within Tennessee Valley Authority land holdings; ${ }^{3}$ Approximate distance in meters from the forest edge; ${ }^{4}$ Total number of P. juglandis collected from trap.

Although all traps used in this study were placed in forest conditions, as defined by USDA FS, trees in more isolated forest settings may not have the same risk from $P$. juglandis or subsequent infection by G. morbida as trees in urban forests. The forest at Maryville College is located within an urbanized area with a history of TCD in the area, which may have enhanced colonization pressure and contributed to high trap catches. Conversely, forested trees at locations in GRSM are more isolated from urban development. Although G. morbida has been found at two locations in GRSM, catches of $P$. juglandis in these areas were low or none. This disparity may indicate that even in areas where individual walnut trees may be infested, trees located in the interior of the forest are buffered by trees 
of other hardwood species from infestation by $P$. juglandis. The effective distance of the lure (i.e., what is the maximum distance the lure will attract $P$. juglandis?) is not known from published literature. However, in field flight tests [19,20] and trapping guidelines [14], the recommended distance to place traps from suspect trees is relatively small (three to five $\mathrm{m}$ ). These distances are used or recommended to insure collections of $P$. juglandis; however, because these published accounts consistently use small distances, the lure may not be effective at distances of 50 to $100 \mathrm{~m}$. Therefore, the collections presented here are likely to be from black walnut trees nearest the traps, rather than from trees greater distances away.

Association with repeated firewood introductions also may play a role in $P$. juglandis occurring in forested black walnut. Both the Big Creek and Cataloochee sites are near campgrounds in the GRSM, and people may unknowingly bring G. morbida-infected or P. juglandis-infested wood to burn while camping. Although the Loyston Point site does not have a history of G. morbida or TCD in as close proximity as the Big Creek or Cataloochee Cove sites, Loyston Point is a popular hunting location, and, therefore, may be subject to hunters and campers bringing infected or infested wood into the area. These findings underscore the importance of preventing the introduction of wood-boring insects and wood-infecting pathogens into new areas via the movement of firewood, and discouraging movement of firewood has become increasingly important in managing several forest pests [21-23].

Branch sampling of all trees from which $P$. juglandis was collected is underway. These branch samples will be examined for $P$. juglandis and tested for G. morbida. Extensive trapping of more interiorly-located walnuts located in larger, more remote (i.e., less human influence) forested sites is planned, and further trapping will enhance our knowledge of the risk $P$. juglandis and G. morbida pose to black walnuts in forests. This knowledge can be applied throughout the native range of walnut, especially areas where forested walnuts occur at great densities [15], to better assess the spread and provide early detection of $P$. juglandis within forest resources.

\section{Acknowledgments}

We thank Donald Bright and Whitney Cranshaw, Colorado State University, for confirmation of identifications of P. juglandis. We thank Bryhana Adams, Dixie Daniels, Renee Follum, Danny Joe Johnson, Robert Lord, and David Paulsen for assistance with deploying, monitoring, and processing traps. We thank Drew Crain, Maryville College, Jack Muncy, Tennessee Valley Authority, Brook Smith, Tennessee Division of Forestry, and Glenn Taylor and Jesse Webster, Great Smoky Mountains National Park, for assistance with determining trapping locations and coordination of trapping efforts. This research was partially funded by the USDA Forest Service, Southern Research Station.

\section{Author Contributions}

Greg Wiggins assisted in the project design and coordinated site selection, deployment, monitoring, and processing of traps, species identification, and compilation and summarization of data. Greg also oversaw the development of this manuscript and is the corresponding author.

Jerome Grant served as Principal Investigator for this project and approved the design and directed the execution of this research. Jerome assisted with development of the overall manuscript, provided critiques, suggestions, and revisions and provided final approval of the version submitted for review. 
Paris Lambdin assisted with the design of this project. Paris also provided contributions to this manuscript through critiques and revisions and provided final approval of the version submitted for review.

Paul Merten provided logistical coordination among cooperators from State and Federal agencies, as well as provided input for selected trap sites. He also facilitated partial funding from the USDA Forest Service for this project. Paul provided critiques and revisions of this manuscript and gave final approval of the version submitted for review.

Katheryne Nix assisted with site selection, deployment and monitoring of traps, trap processing, and tentative species identification. Katheryne provided contributions to this manuscript through critiques and revisions and provided final approval of the version submitted for review.

Denita Hadziabdic contributed to a portion of the project design and execution by facilitating site selection and monitoring of trapping locations on Tennessee Valley Authority land holdings at Loyston Point. Denita provided contributions to this manuscript through critiquing and revising the manuscript and provided final approval of the version to be submitted for review.

Mark Windham assisted with site selection, as well as initial identification of G. morbida from clipped walnut material collected during 2012. Mark provided contributions to this manuscript through critiques and revisions and provided final approval of the version submitted for review.

\section{Conflicts of Interest}

The authors declare no conflict of interest.

\section{References}

1. Williams, R.D. Black walnut. Silvics of North America: Hardwoods; Agriculture Handbook 654; U.S. Department of Agriculture Forest Service: Washington, DC, USA, 1990; pp. 391-399.

2. Newton, L.P.; Fowler, G.; Neeley, A.D.; Schall, R.A.; Takeuchi, Y. Pathway Assessment: Geosmithia sp. and Pityophthorus juglandis Blackman Movement from the Western into the Eastern United States; U.S. Department of Agriculture Animal and Plant Health Inspection Service: Raleigh, NC, USA, 2009; p. 50.

3. Tisserat, N.; Cranshaw, W.; Leatherman, D.; Utley, C.; Alexander, K. Black walnut mortality in Colorado caused by the walnut twig beetle and thousand cankers disease. Plant Health Prog. 2009. Available online: http://www.plantmanagementnetwork.org/pub/php/research/2009/walnut/ (accessed on 3 February 2014).

4. Blackman, M.W. The Genus Pityophthorus Eichh. in North America: A Revisional Study of the Pityophthorini, with Descriptions of Two New Genera and Seventy-One New Species; Bulletin of the New York State College of Forestry Syracuse University: Syracuse, NY, USA, 1928; p. 212.

5. Utley, C.; Nguyen, T.; Roubtsova, T.; Coggeshall, M.; Ford, T.M.; Grauke, L.J.; Graves, A.D.; Leslie, C.A.; McKenna, J.; Woeste, K.; et al. Susceptibility of walnut and hickory species to Geosmithia morbida. Plant Dis. 2013, 97, 601-607.

6. Tisserat, N.; Cranshaw, W. Pest Alert: Walnut Twig Beetle and Thousand Cankers Disease of Black Walnut; Colorado State University, Fort Collins, CO, USA, 2010. Available online: http://www.ext.colostate.edu/pubs/insect/1008_alert.pdf (accessed on 3 February 2014). 
7. Haun, W.G.; Powell, S.; Strohmeier, C.; Kirksey, J. State of Tennessee Thousand Cankers Disease Action Plan; Tennessee Department of Agriculture, Division of Regulatory Services and Division of Forestry: Nashville, TN, USA, 2010. Available online: http://www.tn.gov/ agriculture/publications/regulatory/TN_TCD_ActionPlan.pdf (accessed on 31 January 2014).

8. Grant, J.F.; Windham, M.T.; Haun, W.G.; Wiggins, G.J.; Lambdin, P.L. Initial assessment of thousand cankers disease on black walnut, Juglans nigra, in eastern Tennessee. Forests 2011, 2 , 741-748.

9. Rhodes, D.; O’Hern, C.; Ambe, S.; Hall, T.; Nyce, R.; Newcamp, T.; Turcotte, R.; Bucher, N.; Demko, J.; Donovall, L.; et al. Commonwealth of Pennsylvania Thousand Cankers Disease Action Plan. Pennsylvania Forest Pest Task Force, 2012. Available online: http://www.agriculture.state.pa.us/portal/server.pt/gateway/PTARGS_0_2_24476_10297_0_43/A gWebsite/Files/Publications/PA_TCD_ActionPlanFinal4-13-2012\%20\%282\%291.pdf (accessed on 31 January 2014).

10. Hansen, M.A.; Bush, E.; Day, E.; Griffin, G.; Dart, N. Walnut Thousand Cankers Disease Alert. Virginia Cooperative Extension, 2011. Available online: http:/www.vdacs.virginia.gov/ plant\&pest/pdf/techpestalert.pdf (accessed on 31 January 2014).

11. Hadziabdic, D.G.; Windham, M.T.; Baird, R.; Vito, L.; Cheng, Q.; Grant, J.F.; Lambdin, P.L.; Wiggins, G.J.; Windham, A.; Merten, P.; et al. First report of Geosmithia morbida in North Carolina: The pathogen involved in thousand cankers disease of black walnut. Plant Dis. doi: 10.1094/PDIS-06-13-0630-PDN. Available online: http://dx.doi.org/10.1094/PDIS-06-13-0630PDN (accessed on 31 January 2014).

12. Fisher, J.R.; McCann, D.P.; Taylor, N.J. Geosmithia morbida, thousand cankers disease of black walnut pathogen, was found for the first time in southwestern Ohio. Plant Health Prog. 2013, doi:10.1094/PHP-2013-1201-01-BR. Available online: http://www.plantmanagementnetwork.org/ php/elements/sum2 .aspx?id=10736 (accessed on 18 February 2014).

13. Montecchio, L.; Faccoli, M. First record of thousand cankers disease Geosmithia morbida and walnut twig beetle Pityophthorus juglandis on Juglans nigra in Europe. Plant Disease 2013, 98, 696.

14. Seybold, S.J.; Dallara, P.L.; Hishinuma, S.M.; Flint, M.L. Detecting and Identifying the Walnut Twig Beetle: Monitoring Guidelines for the Invasive Vector of Thousand Cankers Disease of Walnut; UC IPM Program, University of California Agriculture and Natural Resources, 2013. Available online: http://ipm.ucdavis.edu/PDF/PESTNOTES/WTB_trapping.pdf (accessed on 31 January 2014).

15. Randolph, K.C.; Rose, A.K.; Oswalt, C.M.; Brown, M.J. Status of black walnut (Julgans nigra L.) in the eastern United States in light of the discovery of thousand cankers disease. Castanea 2013, $78,2-14$.

16. Tennessee Department of Agriculture, Tennessee Thousand Cankers Disease Quarantine and Buffer Regulated Areas, 2013. Available online: http://www.tn.gov/agriculture/publications/ regulatory/tcd_map.pdf (accessed on 31 January 2014).

17. Eyre, F.H. Forest Cover Types of the United States and Canada; Society of American Foresters: Washington, DC, USA, 2008; p. 148. 
18. U.S. Department of Agriculture Forest Service. Forest Inventory and Analysis National Core Field Guide. Volume 1: Field Data Collection Procedures for Phase 2 Plots. Version 5.1. SRS $M I D A S$; U.S. Department of Agriculture Forest Service, Forest Inventory and Analysis Program, Southern Research Station: Knoxville, TN, USA, 2011; p. 310.

19. Seybold, S.J.; Dallara, P.L.; Nelson, L.J.; Graves, A.D.; Hishinuma, S.M.; Gries, R. Methods of Monitoring and Controlling the Walnut Twig Beetle, Pityophthorus juglandis. US20130014428, A1, 17 January 2014.

20. Seybold, S.J.; King, J.A.; Harris, D.R.; Nelson, L.J.; Hamud, S.M.; Chen, Y. Diurnal flight response of the walnut twig beetle, Pityophthorus juglandis Blackman (Coleoptera: Scolytidae), to pheromone-baited traps in two northern California walnut habitats. Pan Pac. Entomol. 2012, 88, 231-247.

21. U.S. Department of Agriculture. Risk Assessment of the Movement of Firewood within the United States; U.S. Department of Agriculture Animal and Plant Health Inspection Service Plant Protection and Quarantine Center for Plant Health Science and Technology: Raleigh, NC, USA, 2010; p. 111.

22. U.S. Department of Agriculture. Newsroom: Firewood, 2014. Available online: http://www.aphis. usda.gov/newsroom/hot_issues/firewood/ (accessed on 31 January 2014).

23. Don't Move Firewood, 2014. Available online: http://www.dontmovefirewood.org/ (accessed on 31 January 2014).

(C) 2014 by the authors; licensee MDPI, Basel, Switzerland. This article is an open access article distributed under the terms and conditions of the Creative Commons Attribution license (http://creativecommons.org/licenses/by/3.0/). 